\title{
A CHEMICAL AND HISTOCHEMICAL STUDY OF ENZYMES DEPHOSPHORYLATING \\ ADENOSINE PHOSPHATE ESTERS IN THE EPIDIDYMIS OF NORMAT, CASTRATED, AND TESTOSTERONE PROPIONATE TREATED CASTRATED MICE
}

JOHN M. ALLEN ${ }^{1}$ AND JUDITH J. SLATER

Department of Zoology, The University of Michigan

Ann Arbor, Michigan

TWENTY FIGURES

Study of the distribution of acid and alkaline phosphatases in the epididymis of the mouse has shown these enzymes to have widely divergent localizations. Alkaline phosphatase (Allen and Slater, '57) was distributed primarily in the apical portions of the epithelial cells of the head segments of the epididymal canal. Special cells in the head segments and all epithelial cells of the body and tail segments of the canal showed no alkaline phosphatase activity. Acid phosphatase (Allen and Slater, '58) was localized in the Golgi area of epithelial cells in the head segments of the duct. Special cells in the head, body and tail of the epididymal canal showed high levels of activity generally distributed in their cytoplasm. These results indicated that the cells of the epididymal canal were heterogeneous in their enzymatic composition. Since this heterogeneity existed for phosphatases of broad substrate specificity it appeared to us that phosphatases of more restricted substrate characteristics might show further interesting distributional patterns in this tissue. Enzymes dephosphorylating phosphate esters of adenosine form one such group of substrate-restricted enzymes. This paper deals

${ }^{1}$ Work supported by United States Public Health Service Grant C-2751 C-2 and by a grant from the H. H. Rackham School of Graduate Studies of the University of Michigan. 
with the distribution and activity of enzymes hydrolyzing adenosine triphosphate (ATPase), adenosine diphosphate (ADPase), and adenosine monophosphate (AMPase) in the epididymis of normal, castrated, and testosterone propionate treated castrated mice.

\section{METHODS}

All work was carried out on epididymides from 90 to 180 day-old BALB/c Jax male mice. Animals for castration studies were utilized 60 days following operation. Animals for hormone replacement studies were implanted subcutaneously with a single pellet containing $1 \mathrm{mg}$ testosterone propionate and $9 \mathrm{mg}$ cholesterol (Ciba) 30 days after orchidectomy. These animals were utilized 30 days following implantation of the hormone pellets. In order to avoid contributions to quantitative measurements by enzymes contained in spermatozoa, non-orchidectomized control animals were subjected to section of the vasa efferentia. These animals were used for quantitative determinations 60-90 days following the operation. By this time routine histological sections showed the lumen of the epididymal canal to contain few or no sperm cells. A copious eosinophilic secretion was present in the lumen of the duct. Vasectomy had no effect upon the activity of the enzymes involved in this study for histochemical preparations were comparable to those derived from nonvasectomized animals. Histochemical determinations were routinely carried out on non-vasectomized intact male mice.

Histochemical determination of enzymes dephosphorylating adenosine phosphate compounds was made by a modification of the procedure suggested by Padykula and Herman ('55a and $b$ ). The basic substrate mixture for histochemical studies contained the following final concentrations of reactants: $0.033 \mathrm{M}$ sodium diethyl barbiturate, $0.03 \mathrm{M}$ calcium chloride, and $0.005 \mathrm{M}$ adenosine triphosphate (ATP), or $0.005 \mathrm{M}$ adenosine diphosphate (ADP), or $0.01 \mathrm{M}$ adenosine monophosphate (AMP) in the form of the 2-isomer (A2P), the 3-isomer (A3P), or the 5-isomer (A5P), or $0.01 \mathrm{M}$ inosine-5-phosphate 
(I5P). Substrates containing beta-glycerophosphate (GP) were employed as controlis in all cases. The final concentration of beta-glycerophosphate in these control substrate solutions was either $0.005 \mathrm{M}$ or $0.01 \mathrm{M}$ depending on which of the above noted materials was under investigation. $\mathrm{pH}$ was adjusted by the addition of hydrochloric acid or sodium hydroxide to the above substrate solutions and $\mathrm{pH}$ values were measured with a Beckman Model H2 meter. Substrate solutions containing ATP or ADP were routinely used at $\mathrm{pH} 8.5$ while substrate solutions containing A2P, A3P, A5P or I5P were routinely used at pH 7.5. Incubation of sections was carried out at $37^{\circ} \mathrm{C}$ for 4 minutes (ATP), 8 minutes (ADP), or one hour (AMP and I5P) unless otherwise stated. Subsequent to incubation sections were processed according to Gomori ('52).

Cysteine hydrochloride was employed to inhibit the activity of alkaline phosphatase (Padykula and Herman, '55a and b). This material was added as a dry powder to the substrate solution prior to adjustment of the $\mathrm{pH}$. For routine inhibition of alkaline phosphatase activity $0.004 \mathrm{M}$ concentrations of cysteine were satisfactory. Sections for inhibition studies or sections for the routine demonstration of ATPase and ADPase activity in the absence of alkaline phosphatase activity were preincubated at $20^{\circ} \mathrm{C}$ in solutions of cysteine made up in $0.033 \mathrm{M}$ solutions of sodium diethyl barbiturate adjusted to $\mathrm{pH}$ 7.0. This procedure made the inhibition of alkaline phosphatase activity more reliable and did not alter the activity or the distribution of ATPase or ADPase activity.

Tissues for study were sectioned at $10 \mu$ in a microtome cryostat at $-20^{\circ} \mathrm{C}$. Prior to sectioning, these tissues were quick frozen by placing them in a test tube immersed in a slush of dry ice and acetone. Sections were mounted on glass slides with no adhesive. Chemical fixatives were not employed. Before immersion in the substrate solution sections were removed from the cryostat and allowed to dry at room temperature for 5-10 minutes. 
Quantitative determinations of enzyme activity were carried out using a modification of the method employed by us for the determination of acid phosphatase activity (Allen and Slater, '58). Substrate solutions contained; $0.02 \mathrm{M}$ sodium diethyl barbiturate and $0.005 \mathrm{M}$ substrate. Calcium and magnesium ions were added to this stock substrate solution as required. To match histochemical substrates, $0.03 \mathrm{M}$ calcium ion was used in studies of $\mathrm{pH}$, cysteine effects, and endocrine effects. For the determination of ATPase and ADPase activity in the absence of alkaline phosphatase activity, cysteine hydrochloride was added to the substrate mixture to the extent of $0.004 \mathrm{M}$. The $\mathrm{pH}$ was adjusted by the addition of hydrochloric acid or sodium hydroxide prior to final dilution. Routine determination of ATPase and ADPase activity was made at $\mathrm{pH}$ 8.5. A.MPase activity was determined at $\mathrm{pH} 7.5$ in the absence of cysteine. Incubation was at $37^{\circ} \mathrm{C}$. Quantitative determinations were carried out upon total homogenates of epididymides suspended in $0.9 \%$ sodium chloride solutions. Total nitrogen in these homogenates was determined by the method of Levy ('36). Results were expressed as micrograms of phosphorus liberated per milligram of total nitrogen per minute.

Data were analyzed using standard statistical methods. Homogeneity of variances was tested by application of the F-test. When variances were homogeneous the normal T-test was applied to obtain probability values $(P)$. When variances were inhomogeneous the Cochran-Cox ('50) modification of the T-test was applied to obtain probability $\left(\mathrm{P}^{*}\right)$ values.

\section{RESULTS}

General features of enzymatic activity against ATP and $A D P$ in the epididymis of normal control mice. Sections incubated in substrates containing ATP and ADP showed, in addition to a typical alkaline phosphatase reaction, a localization attributable to ATPase and ADPase activity (see below) (figs. 3 and 4). The alkaline phosphatase distribution has 
been described (Allen and Slater, '57) and requires no further comment except to add that the pattern observed with beta-glycerophosphate at $\mathrm{pH} 9.5$ was identical to that noted earlier with sodium alpha-naphthyl acid phosphate at $\mathrm{pH}$ 9.2. Alkaline phosphatase activity against the substrates employed in this study was drastically curtailed by the use of cysteine. Examination of sections incubated at $\mathrm{pH} 9.5$ for up to 8 minutes in substrate solutions containing $0.001,0.002$, $0.004,0.008$, and $0.016 \mathrm{M}$ cysteine in addition to $0.005 \mathrm{M} \mathrm{ATP}$, ADP or GP showed virtually complete inhibition of the alkaline phosphatase pattern at concentrations of $0.004 \mathrm{M}$ cysteine or greater (figs. 7 and 9). This concentration of cysteine had no apparent effect upon the activity of ATPase or ADPase although higher cysteine concentrations did exert slight inhibitory effects. Similar effects were obtained when substrate solutions were buffered at $\mathrm{pH}$ 8.5. Quantitative determination of the effect of cysteine upon the activity of alkaline phosphatase activity confirmed the histochemical observations (fig. 1).

Cytochemical studies of the influence of $\mathrm{pH}$ upon the ability of epididymis to hydrolyze ATP and ADP were carricd out. Substrate solutions for these studies were adjusted to $\mathrm{pH}$ values of $9.5,9.0,8.5,8.0$, and 7.5 and contained either 0.004 M cysteine or no cysteine. Sections for ATP studies were incubated 4 minutes and for ADP studies 8 minutes. Maximal activity against ATP and ADP was noted at $\mathrm{pH}$ 8.5. These results were in contrast to those obtained when GP (without cysteine) was used as a substrate. In this case $\mathrm{pH}$. 9.5 yielded maximal activity. Quantitative observations confirmed and extended the cytochemical studies. These quantitative estimations indicated that both ATP and ADP were maximally hydrolyzed in the region of $\mathrm{pH} 8.5$ (fig. 2). As $\mathrm{pH}$ values approached neutrality activity against ATP declined. Activity against ADP, however, increased between $\mathrm{pH} 8.0$ and $\mathrm{pH} 7.5$.

The influence of calcium and magnesium ions upon the ability of epididymis to hydrolyze ATP and ADP was in- 
vestigated. Cytochemical investigation was restricted to the addition of magnesium ion. Magnesium at a final concentration of $0.0025 \mathrm{M}$ had no effect upon the activity of epididymis against ATP and ADP. Quantitative studies, however, indi-

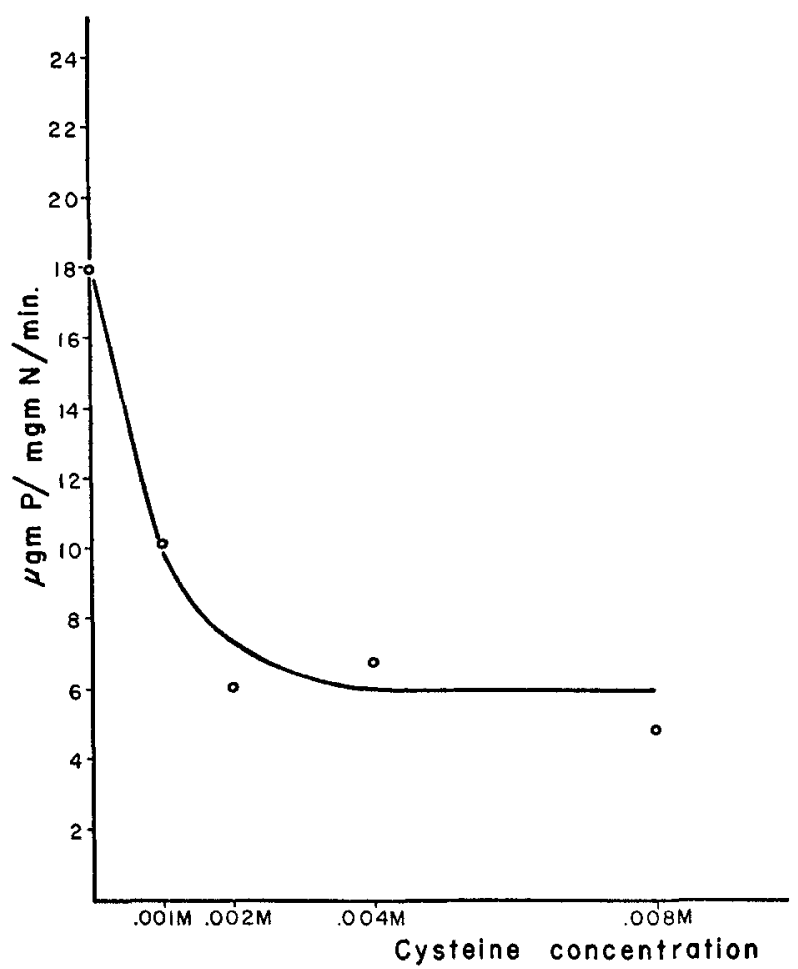

Fig. 1 Effect of various concentrations of eysteine upon the activity of total homogenates of epididymides from normal control animals against beta-glycerophosphate at $\mathrm{pH}$ 8.5. Each point on the graph represents a mean activity derived from determinations on a minimum of 5 animals.

cated that both calcium and magnesium exert significant effects upon the ability of epididymis to hydrolyze ATP and ADP (table 1). Substrate solutions for these studies contained $0.004 \mathrm{M}$ cysteine. Glycerophosphate substrate solutions containing $0.004 \mathrm{M}$ cysteine served as controls. For the purposes of calculation the activity against these glycero- 
phosphate substrate solutions was subtracted from the values obtained when ATP or ADP were used as substrates. This correction for residual alkaline phosphatase activity was based upon the assumption that this enzyme hydrolyzed ATP and ADP as rapidly as it did GP. Cytochemical preparations

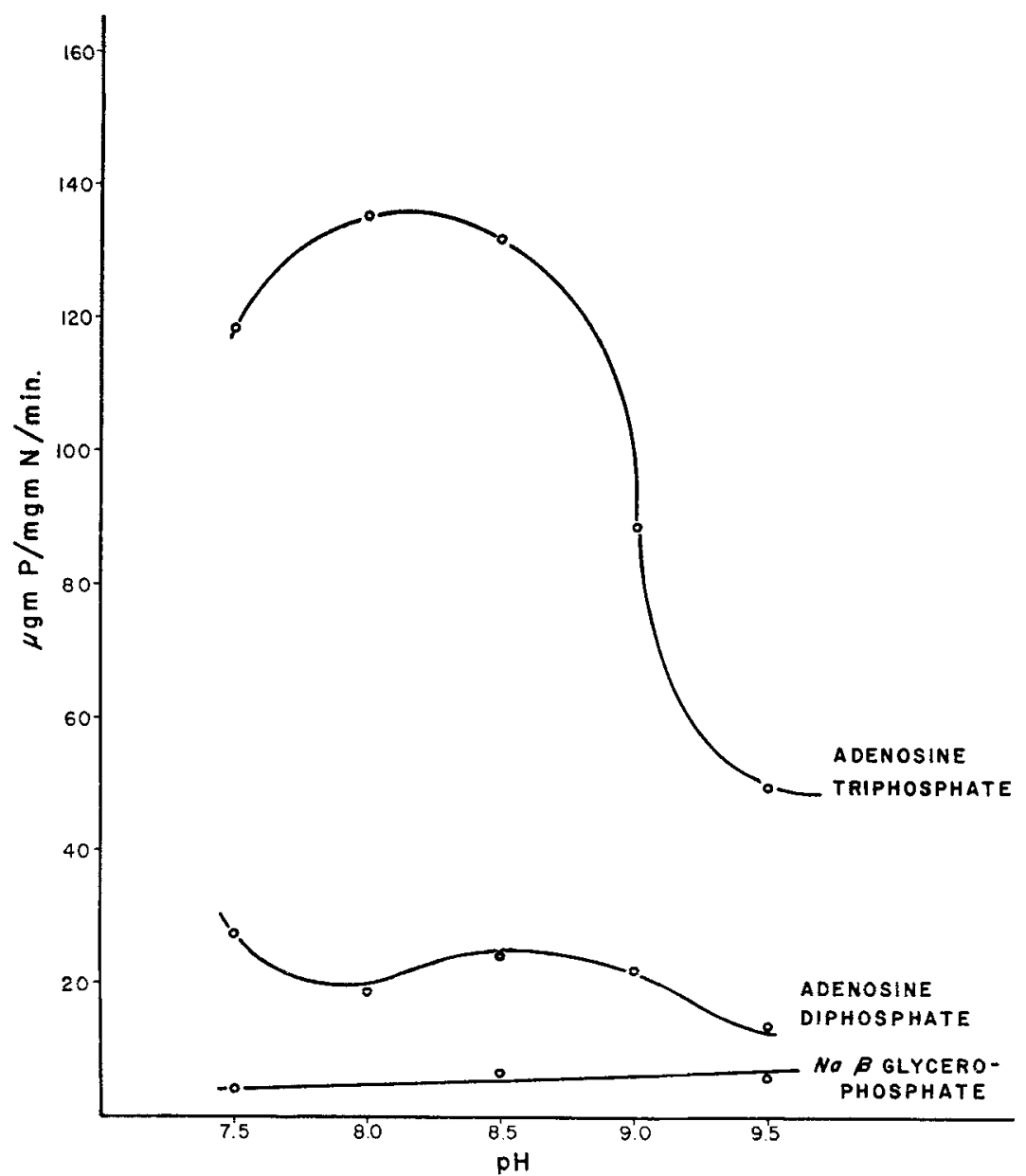

Fig. 2 Effect of variation of pII upon the activity of total homogenates of epididymides from normal control animals against $0.005 \mathrm{M}$ beta-glycerophopshate, $0.005 \mathrm{M}$ adenosine triphosphate, and $0.005 \mathrm{M}$ adenosine diphosphate. Substrate solutions for these determinations contained $0.004 \mathrm{M}$ cysteine. Fach point on the graph represents a mean activity derived from determination on a minimum of 5 animals. 


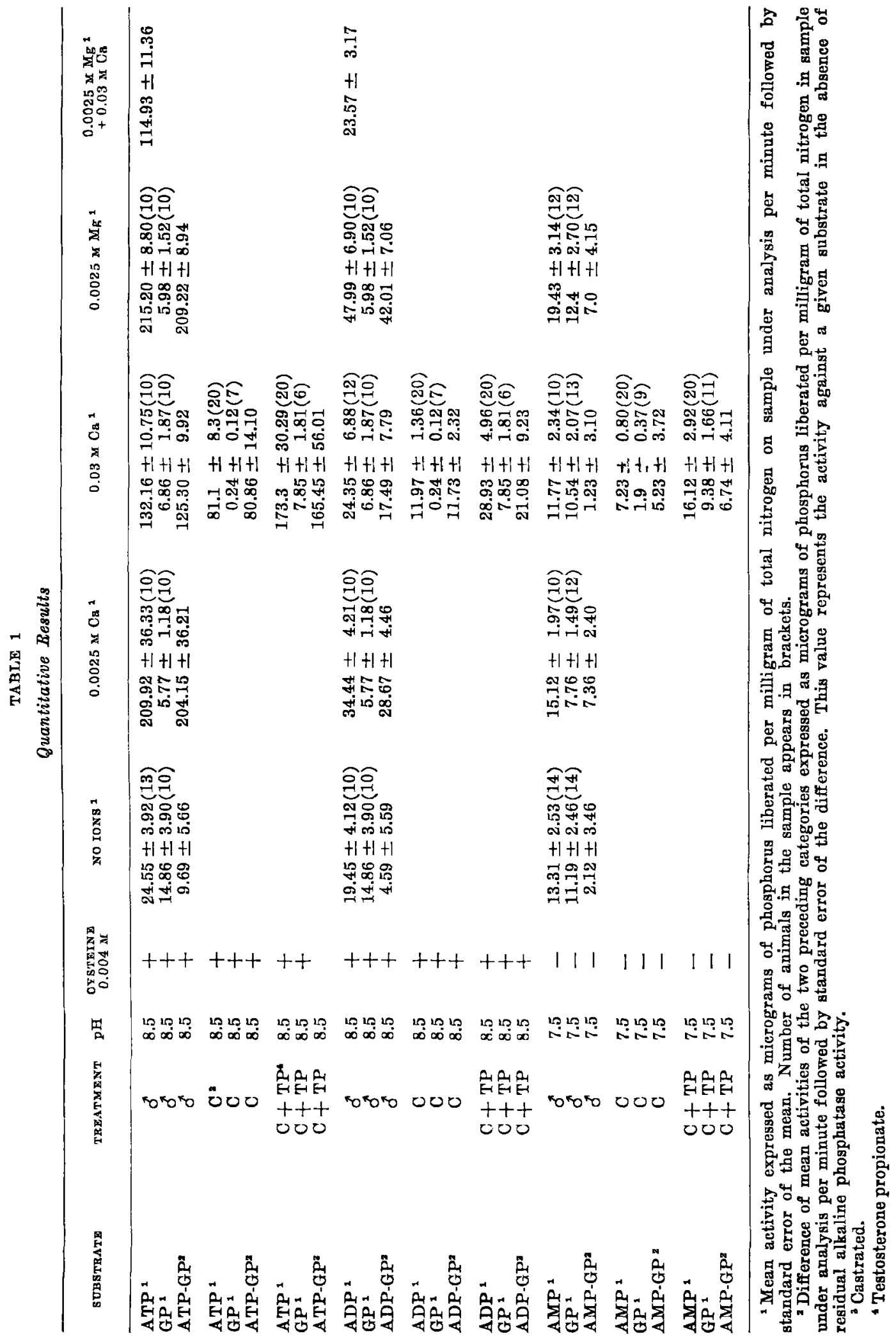


supported this assumption. Under these circumstances it was found that low concentrations of calcium ion $(0.0025 \mathrm{M})$ caused significant elevation of activity against $\operatorname{ATP}\left(\mathrm{P}^{*}=\right.$ 0.01). Concentrations of calcium ion equal to those used in histochemical substrates $(0.03 \mathrm{M})$ also significantly elevated activity against ATP $\left(\mathrm{P}^{*}=0.01\right)$. Comparison of the effects of $0.0025 \mathrm{M}$ calcium and $0.03 \mathrm{M}$ calcium indicated that the higher concentration exerted an inhibitory action on hydrolysis of ATP $\left(\mathrm{P}^{*}=0.05\right)$. Magnesium ion exerted a stimulatory effect on activity against ATP at a concentration of $0.0025 \mathrm{M}\left(\mathrm{P}^{*}<0.05\right)$. This effect was comparable in magnitude to that exerted by $0.0025 \mathrm{M}$ calcium ion $\left(\mathrm{P}^{*}>0.05\right)$. In the presence of $0.03 \mathrm{M}$ calcium ion, however, $0.0025 \mathrm{M}$ magnesium ion exerted no activating influence $(\mathrm{P}>0.05)$.

Activity of epididymis against ADP was not affected by calcium ion concentrations of $0.0025 \mathrm{M}$ or $0.03 \mathrm{M}\left(\mathrm{P}^{*}>0.05\right)$. Magnesium ion at $0.0025 \mathrm{M}$ concentration significantly increased the activity against ADP $\left(\mathrm{P}^{*}<0.01\right)$. Magnesium ion at a concentration of $0.0025 \mathrm{M}$ in combination with $0.03 \mathrm{M}$ calcium ion exerted no effect on ADP hydrolysis $(\mathrm{P}>0.05)$.

The topography of activity against ATP in the absence of alkaline phosphatase. Sections incubated in substrate solutions containing ATP and $0.004 \mathrm{M}$ cysteine showed an absence of activity in the majority of the epithelial cells lining the epididymal canal (figs. 7 and 8). An exception was found in the case of those special cells located in the head segment of the epididymal duct (Allen and Slater, '57, '58). The apical portion of these cells gave a strong reaction (fig. 5). Following prolonged incubation (up to 30 minutes) generalized greying of the duct epithelium occurred.

High activity was noted in the sub-epithelial connective tissue stroma of all regions of the epididymis (figs. 7 and 8). The basement membrane in those tail segments of the duct which were associated with prominent muscle layers also gave a strong reaction (fig. 8). Moderate activity was present in the muscle coats of the tail segments of the canal (fig. 8), in capillary endothelium (fig. 7) and in unidentified 
elements associated with the interductal connective tissue stroma (fig. 7). No regional difference in the activity of any of these elements was noted.

Topography of activity against ADP in the absence of alkaline phosphatase. Activity against ADP was absent from the majority of epithelial cells of the epididymal duct (figs. 9 and 10). The special cells in head lobe 3 showed a strong reaction in the apical portion of the cytoplasm (fig. 6). Strong activity against ADP was also found in the capillary endothelium (fig. 9). Moderate to low activity resided in the muscle coats of the tail segments of the canal (fig. 10) and in the sub-epithelial connective tissue stroma of all regions of the epididymis (fig. 9). Low activity was present in the basement membrane of the tail portions of the duct associated with prominent muscle layers (fig. 10). The interlobular connective tissue cells which showed moderate activity when ATP was employed as a substrate were unreactive with ADP (fig. 9).

Camparison of the topography of activity against ATP and $A D P$ in the absence of alkaline phosphatase. The general features of the distribution of activity against ATP and ADP were similar but points of difference were apparent particularly in the relative activity of various tissue components. These differences are summarized in table 2.

The effect of castration upon activity against ATP and $A D P$ in the absence of alkaline phosphatase. Castration effects on the activity against ATP and ADP were difficult to determine from eytochemical preparations. Activity against ATP in capillary endothelium was unaffected by orchidectomy (fig. 12) but activity in the submucosal and inter-tubular connective tissue was slightly depressed (fig. 11), and activity in the muscle coats of the tail portions of the epididymis was increased slightly (fig. 12). Activity against ADP in the capillary endothelium was unaffected by castration (fig. 13) but the activity in the muscle coats of the tail (fig. 14) and the submucosal connective tissue of all regions of the epididymis (fig. 13) was increased considerably. The 
activity of the special cells seen in head lobe 3 was abolished by orchidectomy when either ATP or ADP were used as substrates. Quantitative determinations (table 1) indicated a significant drop in activity against ATP following castration $\left(\mathrm{P}^{*}=0.01\right)$ but activity against ADP was not affected by this treatment $\left(\mathrm{P}^{*}>0.05\right)$.

The effect of testosterone propionate administration to castrated animals upon activity against $A T P$ and $A D P$ in the absence of alkaline phosphatase. Cytochemical preparations indicated that treatment with testosterone propionate

TABLE 2

Comparison of the relative activity of tissue components in mouse epididymis when ATP and ADP are used as substrates

\begin{tabular}{lcc}
\hline & \multicolumn{1}{c}{ ATP $^{{ }^{2}}$} & ADP $^{{ }^{1}}$ \\
\hline General epithelium & - & - \\
Special cells & ++++ & +++ \\
Musele coats & +++ & + \\
Basement membrane & ++++ & + \\
Capillary endothelium & ++ & ++++ \\
Sub-epithelial connective tissue stroma & ++++ & + \\
Un-identified inter-tubular cells & ++ & -
\end{tabular}

${ }^{1}$ Comparison made at 4 minutes incubation in presence of $0.004 \mathrm{M}$ cysteine with activity of all components referred to the reactivity of sub-epithelial connective tissue in the presence of ATP. Designation $(++++)$ indicates maximum activity and ( $\rightarrow$ ) indicates no activity.

restored the activity pattern against ATP and ADP to normal (figs. 15, 16, 17 and 18). Quantitative determinations of activity against ATP indicated a significant elevation above castrate levels following treatment with testosterone propionate $\left(\mathrm{P}^{*}<0.05\right)$. Comparison of activity against ATP in tissues from normal control animals with those from testosterone propionate treated castrated animals showed no difference between these groups $\left(\mathrm{P}^{*}>0.05\right)$. Testosterone propionate treatment of castrated animals had no effect upon activity against ADP when compared to that present in tissues derived from normal or castrated mice $\left(\mathrm{P}^{*}>0.05\right)$. 
The general features of enzyme activity against AMP in the epididymis of normal, castrated, and testosterone propionate treated castrated animals. The distributions of activity against GP and A5P at $\mathrm{pH} 7.5$ were different. Sections incubated one hour in substrate solutions containing GP showed a localization of activity which was restricted to the apical portions of epithelial cells in head lobes 3-7 and all other tissue components were negative. Tissues incubated for the same time in substrate solutions containing A5P showed, in addition to this reaction in the apical portions of the epithelial cells in head lobes 3-7 (fig. 19), a strong reaction in the muscle coats of the tail (fig. 20). Use of $0.004 \mathrm{M}$ cysteine completely abolished reactivity against both GP and $\mathrm{A} 5 \mathrm{P}$ at $\mathrm{pH} 7.5,8.5$ and 9.5. Substrate solutions containing I5P yielded patterns and intensities of reaction equivalent to those obtained with A5P. This reaction was also abolished by $0.004 \mathrm{M}$ cysteine. Substrate solutions containing A2P and A3P gave no reaction on incubation up to 8 hours in duration.

Sections of epididymides from normal, castrated, and castrated animals treated with testosterone propionate showed equivalent patterns and intensities of reaction when $\mathrm{A5P}$ was used as the substrate.

Quantitative determinations (table 1) showed no significant difference in the ability of homogenates of epididymides from normal, castrated, or castrated animals treated with testosterone propionate to hydrolyze GP and A5P $(\mathrm{P}>0.05)$. No effect of $0.0025 \mathrm{M}$ magnesium ion, $0.0025 \mathrm{M}$ calcium ion, or $0.03 \mathrm{M}$ calcium ion upon the activity of tissues derived from normal control animals could be detected when A5P or GP were used as substrates $(\mathrm{P}>0.05)$. Tissues from normal, castrated, and castrated animals treated with testosterone propionate showed equivalent activity when A5P was used as a substrate $(\mathrm{P}>0.05)$.

\section{DISCUSSION}

The above data indicates a surprising distribution of enzymes hydrolyzing phosphoadenine esters. The presence of 
these enzymes in the muscle tissue of the epididymis is expected in view of their involvement in muscle physiology. Their high activity in the connective tissue stroma in contrast to their low activity in the epithelium is intriguing. No surveys of the distribution of enzymes hydrolyzing phosphoadenine esters have been carried out but sections of several tissues figured by Padykula and Herman ('55 a and b) do not indicate the presence of this activity in connective tissue as a general phenomenon. It is possible that the stromal locale of enzymes hydrolyzing ATP and ADP is a special feature of this tissue and may be of significance in its physiology. The presence of high activity against ATP and ADP in the special non-ciliated cells in head lobe 3 serves as a contrast between these cells and those ciliated epithelial cells with which they are associated. Previous studies (Allen and Slater, '57, '58) have contrasted these cells with the ciliated cells on the basis of their high aliesterase and acid phosphatase activity.

This study indicates that the techniques developed by Padykula and Herman ('55) make possible the separation in epididymis of a category of enzymes hydrolyzing phosphoadenine esters which is distinct from alkaline phosphatase. All of the ribotides employed by us were hydrolyzed by alkaline phosphate. Cysteine, in proper concentration, abolished the alkaline phosphatase activity but did not affect a component of hydrolytic activity residing primarily in the muscular and stromal tissues. This latter enzymatic component is active against $\mathrm{ATP}$ and $\mathrm{ADP}$ but is inactive against AMP. AMP is apparently hydrolyzed by an enzyme(s) distinct from alkaline phosphatase for at $\mathrm{pH} 7.5$ the distribution patterns obtained with $\mathrm{GP}$ and A5P are different. This enzyme has the substrate characteristics commonly accepted for 5-nucleotidease (Laskowski, '51). It hydrolyzes A5P and $\mathrm{I} 5 \mathrm{P}$ at equal rates but does not attack $\mathrm{A} 2 \mathrm{P}$ and $\mathrm{A} 3 \mathrm{P}$. The component of cysteine resistant activity hydrolyzing ATP and ADP may be subdivided into two categories (a) an ATPase and (b) an ADPase. This subdivision is based upon 
$\mathrm{pH}$ response, effect of added calcium and magnesium ions, upon behavior following orchidectomy or testosterone propionate treatment, and upon the histochemical distributional profile.

Of the three categories of hydrolytic activity observed (ATPase, ADPase, and AMPase) only that directed toward ATP is sensitive to deprivation of androgenic hormone. The enzymes hydrolyzing ADP and A.5P were not affected significantly by castration. The failure of these latter enzymes to show an endocrine relation is in contrast to the behavior of alkaline phosphatase, acid phosphatase and aliesterase in the epididymis (Allen and Slater, '57, '58). The activity of these enzymes, like ATPase, was radically depressed by orchidectomy. Recent work has further defined the endocrine response of alkaline phosphatase, acid phosphatase and aliesterase in mouse epididymis. Using starch matrix electrophoresis combined with cytochemical localizing techniques Allen and Hunter ('59) have shown that only some components of the esterase system in this tissue are sensitive to androgen deprivation. The response of this system to androgen lack is a reflection of the behavior of the individual members of the esterase population, some of which are abolished, some only slightly depressed and others unaffected. The enzymes demonstrated in the present study represent another system (adenosine phosphatases) in which the endocrine response among the members of the population is variable.

The restriction of enzymes hydrolyzing ATP and ADP to connective tissue suggests a dichotomy of function between the epithelial and stromal tissues of the epididymis of the mouse. Recent experimental work has established that an element of physiological cooperation or interaction exists between cells of certain tissues. Such interacting systems have been studied in ascitic tumor cells by Sato et al. ('57), in mouse sub-mandibular gland by Grobstein ('53), and in chick heart tissue by Markert ('56). It is possible that the restriction of hydrolytic activity against ATP and ADP to 
stromal tissue in the epididymis of the mouse represents another such interacting system. If so, what physiological significance may be attached to these enzymes hydrolyzing ATP and ADP? There is reason to believe (Axelrod, '56) that many enzymes exhibiting hydrolase activity in simple assay systems also possess transferase activity as well. It may be that the ATPase activity noted in the present study is actually part of a more complex synthetase or transferase system which is confined to the connective tissue stroma. This system could cooperate with other systems located in the epithelial cells of the epididymis to maintain normal metabolism or it could function to control oxidative phosphorylation in the epithelial cells by regulating the availability of ADP (Chance, '56).

\section{SUMMARY}

The activity of enzymes hydrolyzing adenosine triphosphate, adenosine diphosphate, and adenosine monophosphate in the epididymis of normal, castrated, and castrated mice treated with testosterone propionate has been investigated with histochemical and quantitative methods. Cysteine was employed to inhibit the activity of alkaline phosphatase. Enzymes hydrolyzing adenosine triphosphate and adenosine diphosphate were restricted to the muscular and connective tissues and capillary endothelium with the exception of activity present in non-ciliated epithelial cells in head lobe 3. Activity against adenosine monophosphate was present only in the muscular tissues. Differences in the pattern of activity levels were noted when adenosine triphosphate and adenosine diphosphate were used as substrates. Quantitative determinations indicated that activity against adenosine triphophate was enhanced by the addition of calcium and magnesium ions but activity against adenosine diphosphate was enhanced by magnesium ion and unaffected by calcium ion. Calcium and magnesium ion had no effect upon activity against adenosine monophosphate. Quantitative determinations also indicated that activity against adenosine triphosphate was depressed 
by orchidectomy but that activity against adenosine diphosphate and adenosine monophosphate was unaffected by this treatment. Testosterone propionate administration restored activity against adenosine triphosphate to control levels but had no effect upon activity against adenosine diphosphate and adenosine monophosphate. It is concluded that separate adenosine triphosphatases, adenosine diphosphatases, and adenosine monophosphatases exist in the epididymis of the mouse.

\section{LITERATURE CITED}

ALLeN, J., AND R. HunTer 1959 A histochemical study of enzymes in the epididymis of normal, castrated and hormone replaced castrated mice separated by zone electrophoresis in starch gels. J. Histochem. Cytochem., accepted for publication.

ALLeN, J., AND J. SLATER 1957 A chemical and histochemical study of alkaline phosphatase and aliesterase in the epididymis of normal and eastrate mice. Anat. Rec., 199: 255-273.

1958 A chemical and histochemical study of acid phosphatase in the epididymis of normal, castrate and hormone replaced eastrate mice. Anat. Rec, 130: 731-745.

AxELRod, B. 1956 Enzymatic phosphate transfer. In: Advances in Enzymology, ed. F. Nord. Interscience Publishers, Ine., New York, pp. 159-188.

Chance, B., AND G. Willidams 1956 The respiratory chain and oxidative phosphorylation. In: Advances in Enzymology, ed. F. Nord. Interseience Publishers, Inc., New York, pp. 65-134.

Cochran, W., and G. Cox 1950 Experimental Designs. John Wiley and Sons, Inc., New York.

Gomori, G. 1952 Microseopic Histochemistry. The University of Chicago Press, Chicago, p. 184.

Grobstein, C. 1953 Epithelio-mesenchymal specifieity in the morphogenesis of mouse sub-mandibular rudiments in vitro. J. Exp. Zool., 121: 383-414.

Laskowski, M. 1951 Nucleolytic enzymes. In: The Enzymes, ed. J. Sumner and K. Myrbäck, Academic Press, Inc., New York, Vol. I, Chapt. 29, pp. $975-976$.

LEVr, M. 1936 Studies on enzymatie histochemistry. XVIT. A miero Kjeldahl estimation. C. R. Trav. Carlsberg, Sér. chim., 21: 101-110.

MARKERT, C. 1956 The ontogeny of divergent metabolie patterns in eells of identical genotype. Cold Spring Harb. Symp. Quant. Biol., 81: 339-348.

Padykula, H., and E. Herman 1955a Factors affecting the activity of adenosine triphosphatase and other phosphatases as measured by histochemical techniques. J. Histochem. Cytochem., 3: 161-169.

$1955 \mathrm{~b}$ The specificity of the histochemical method for adenosine triphosphatase. Ibid., 3 : 170-195.

SAto, G., H. FIsher aND T. PUCK 1957 Molecular growth requirements of single mammalian cells. Science, 196: 961-964. 
PLATES 


\section{PLATE 1}

\section{EXPLANATION OF FIGURES}

3 Distribution of activity against adenosine triphosphate in the absence of eysteine in the mid-head region of epididymis from a normal control animal. Note the high activity in the apical portions of the epithelial cells. This activity is abolished by 0.004 cysteine (fig. 7 ) ; 4 min. ineubation, $\times 85$.

4 Distribution of activity against adenosine diphosphate in the absence of eysteine in the mid-head region of epididymis from a normal control animal. The activity in the apical portions of the epithelial cells is comparable to that seen in figure 3 . This activity is abolished by $0.004 \mathrm{M}$ eysteine (fig. 9); 8 min. incubation, $\times 85$.

5 Distribution of activity against adenosine triphosphate in the presence of $0.004 \mathrm{M}$ cysteine in head lobe 3 of epididymis from a normal control animal. High activity is present in the apical portions of the non-ciliated epithelial cells in this region; 4 min. incubation, $\times 125$.

6 Distribution of activity against adenosine diphosphate in the presence of $0.004 \mathrm{M}$ eysteine in head lobe 3 of epididymis from a normal control animal. High activity is present in the apical portions of the non-ciliated epithelial cells in this region; $8 \mathrm{~min}$. incubation, $\times 125$.

7 Distribution of activity against adenosine triphosphate in the presence of $0.004 \mathrm{M}$ cysteine in the mid-head region of epididymis from a normal control animal. Note the absence of alkaline phosphatase activity; $4 \mathrm{~min}$. incubation, $\times 85$.

8 Distribution of activity against adenosine diphosphate in the presence of $0.004 \mathrm{M}$ cysteine in the mid-tail region of epididymis from a normal control animal; 4 min. ineubation, $\times 85$. 

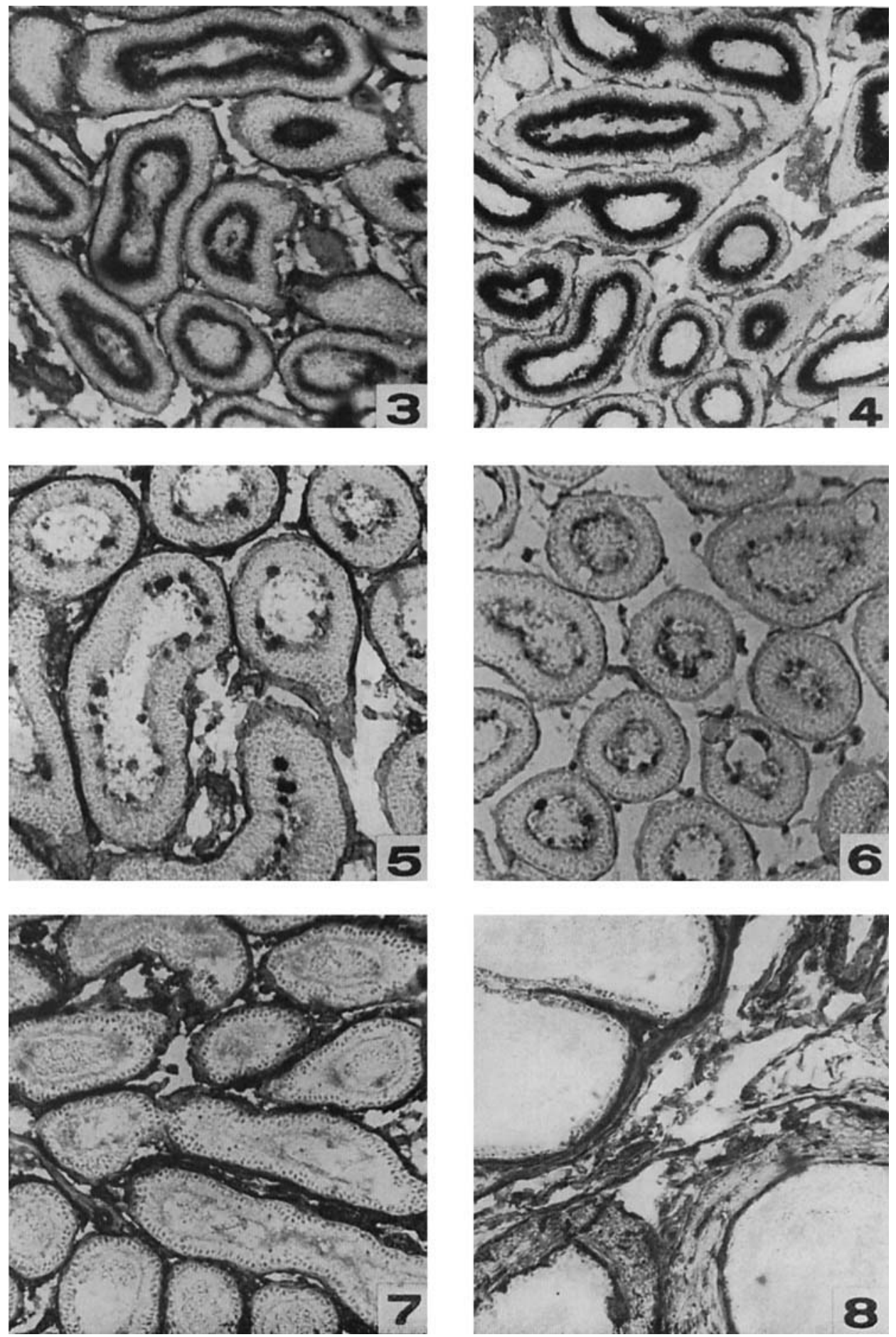


\section{PLATE 2}

\section{EXPLANATION OF FIGURES}

9 Distribution of activity against adenosine diphosphate in the presence of $0.004 \mathrm{M}$ eysteine in the mid-head region of epididymis from a normal control animal. Note the absence of alkaline phosphatase activity; $8 \mathrm{~min}$. incubation, $\times 85$.

10 Distribution of activity against adenosine diphosphate in the presence of $0.004 \mathrm{M}$ cysteine in the mid-tail region of epididymis from a normal control animal; 8 min. ineubation, $\times 85$.

11 Distribution of activity against adenosine triphosphate in the presence of $0.004 \mathrm{M}$ eysteine in the mid-head region of epididymis from an animal eastrated for 60 days. Compare with figure $7 ; 4$ min. incubation, $\times 85$.

12 Distribution of activity against adenosine triphosphate in the presence of $0.004 \mathrm{M}$ eysteine in the mid-tail region of epididymis from an animal castrated for 60 days. Compare with figure $8 ; 4$ min. ineubation, $\times 85$.

13 Distribution of activity against adenosine diphosphate in the presence of $0.004 \mathrm{M}$ eysteine in the mid-head region of epididymis from an animal eastrated for 60 days. Compare with figure $9 ; 8$ min. incubation, $\times 85$.

14 Distribution of activity against adenosine diphosphate in the presence of $0.004 \mathrm{M}$ cysteine in the mid-tail region of epididymis from an animal castrated for 60 days. Compare with figure $10 ; 8 \mathrm{~min}$. incubation, $\times 85$. 
FPIDIDYMAL ADENOSINE PJIOSPIATASES

PLATE 2

JOHN M. ALERN AND TUDLTH J. SLATER
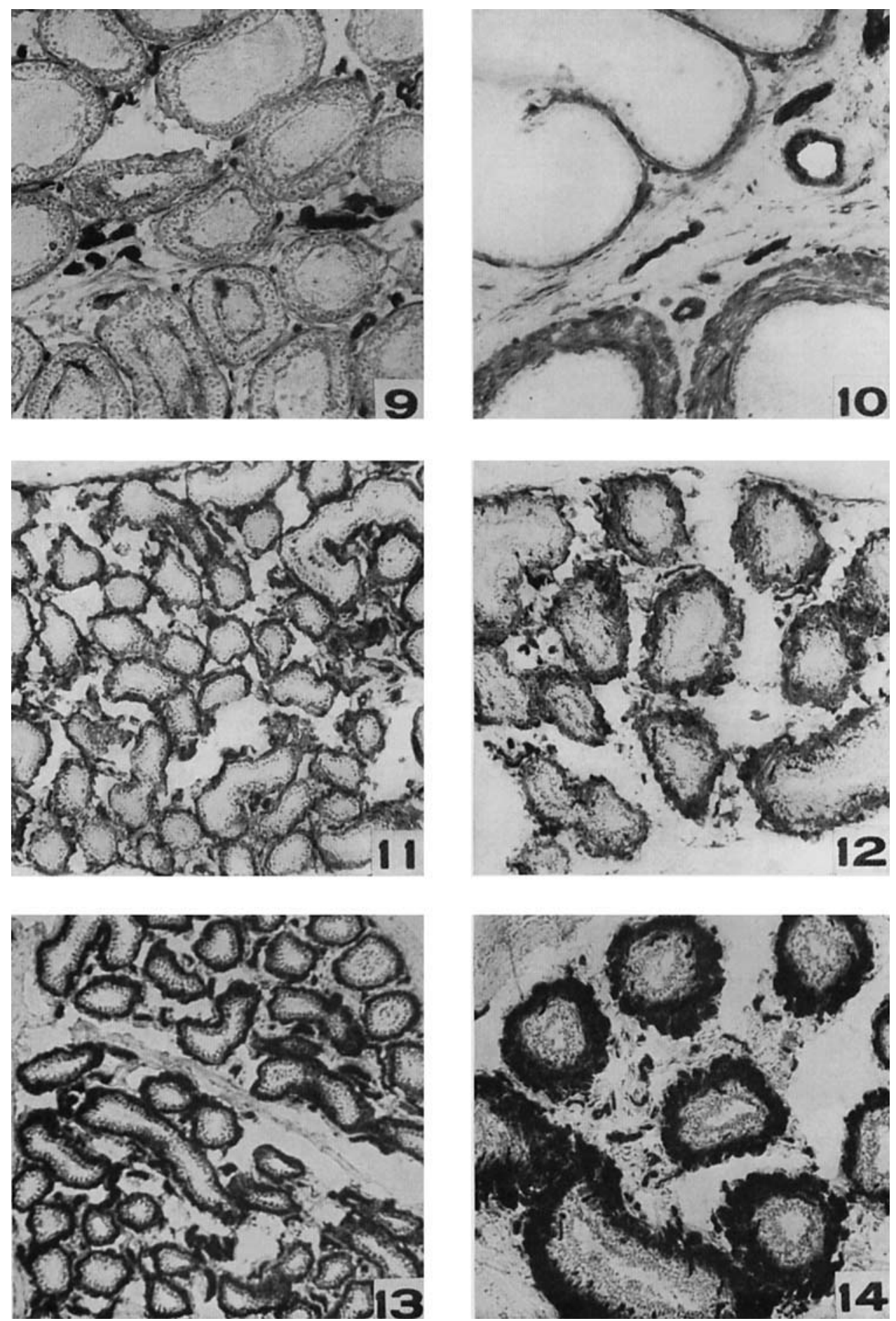
PLATE 3

EXPLANATION OF FIGURES

15 Distribution of activity against adenosine triphosphate in the presence of 0.004 Mr cysteine in the mid-head region of epididymis from an animal castrated for 30 days and treated with testosterone propionate for 30 days. Compare with figures 7 and $11 ; 4$ min. incubation, $\times 85$.

16 Distribution of activity against artenosine triphosphate in the presence of $0.004 \mathrm{M}$ cysteine in the mid-tail region of epididymis from an animal castrated for 30 days and treated with testosterone propionate for 30 days. Compare with figures 8 and $12 ; 4$ min. incubation, $\times 85$.

17 Distribution of activity against adenosine diphosphate in the presence of $0.004 \mathrm{M}$ cysteine in the mid-head region of epididymis from an animal castrated for 30 days and treated with testosterone propionate for 30 days. Compare with figures 9 and $13 ; 8$ min. incubation, $\times 85$.

18 Distribution of activity against adcuosine diphosphate in the presence of $0.004 \mathrm{M}$ eystcine in the mid-tail region of epididymis from an animal castrated for 30 days and treated with testosterone propionate for 30 days. Compare with figures 10 and $14 ; 8$ min. ineubation, $X 85$.

19 Distribution of activity against adenosine 5-phosphate in the mid-head region of epididymis from normal control animal. The activity seen in the figure is due to alkaline phosphatase. One hour incubation, $\times 85$.

20 Distribution of activity against adenosine 5-phosphate in the mid-tail region of epididymis from normal control animal. The activity seen in this figure is due to 5-nucleotidase activity. Control sections incubated in substrate solutions containing beta-glyeerophosphate were completely negative. Ono hour incubation, $\times 85$. 
EPIDIDYMAL ADENOSINE PHOSPHATASES

PIAATE 3

JOHN M. ALLEN AND JUDTTH J. SLATER
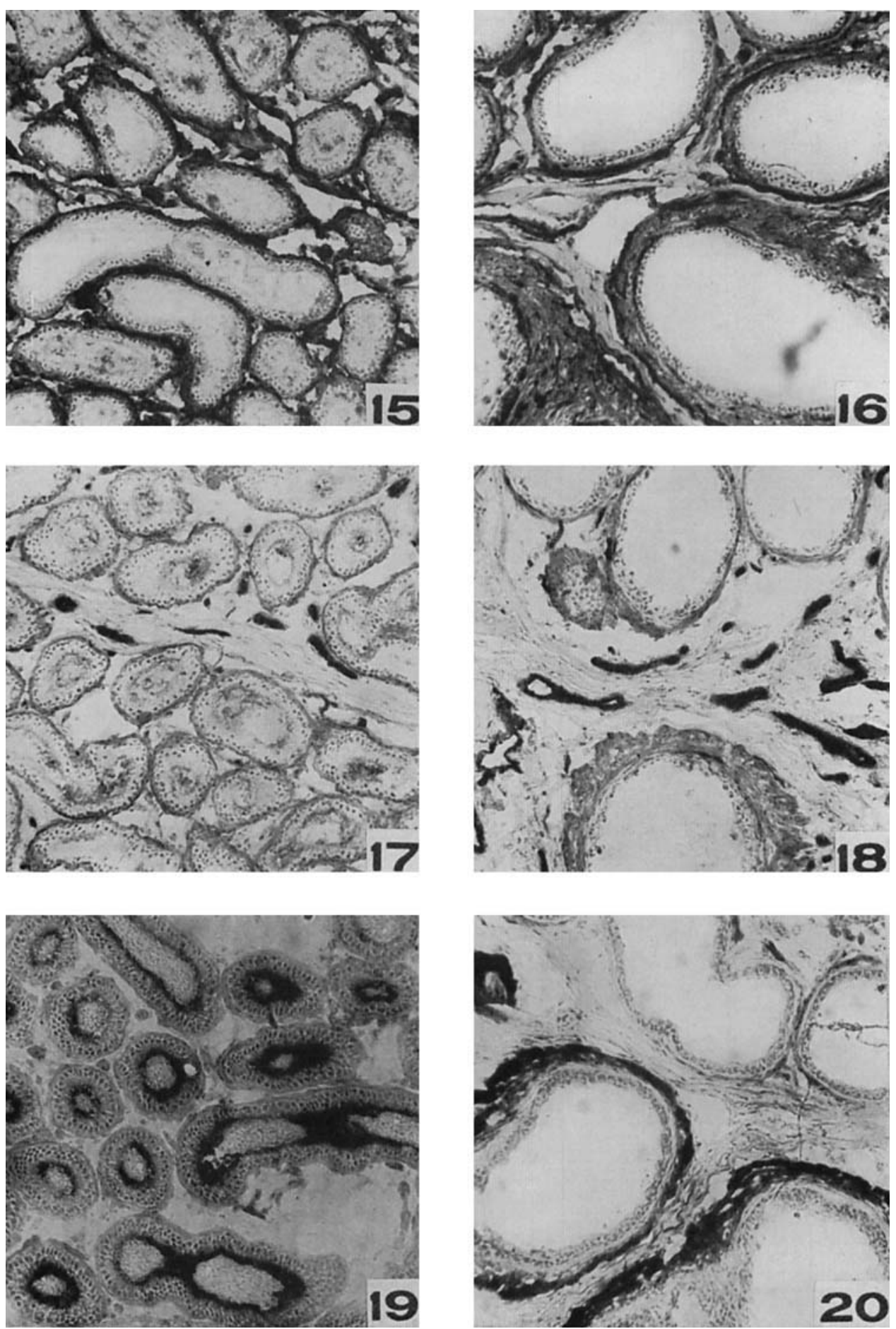